\title{
Humanitarian Law Perspective on the Protection of the Rights of Children in Armed Conflicts
}

\section{Perlindungan Hak-Hak Anak dalam Sengketa Bersenjata Menurut Hukum Humaniter}

\author{
Yared Hetharie $^{1} \otimes$, Yosia Hetharie ${ }^{2}$ \\ 1,2 Faculty of Law, Universitas Pattimura, Ambon, Indonesia \\ ⓨaredhetharie27@gmail.com
}

\begin{abstract}
Children are often victims of armed disputes, not only in the case they are trapped in situations of armed conflict but also children are often included directly as child soldiers, therefore children must be given protection to obtain their rights as a child in an armed dispute. Child protection is closely related to Human Rights that have been generally recognized by the international community. International legal instruments and national law have regulated the protection of children's rights. Countries that are involved in armed disputes and do not implement the provisions of humanitarian law in particular the protection of the rights of the child and are considered a war crime. This research is a legal research, which is a process to find the rule of law, legal principles, and legal doctrines in order to answer the legal issues faced with the approach used is the legal approach, which is carried out by examining all laws and regulations relating to the legal issues being addressed. Countries that have not ratified the provisions of Humanitarian law, should be able to ratify the provisions of Humanitarian law regarding the protection of children from being directly involved in armed disputes, and implement them into armed disputes, and implement them into their respective national legislation each country.
\end{abstract}

Keywords: Child Protection, Armed Conflicts, Human Rights, Humanitarian Law

\section{Pendahuluan}

Anak - anak dapat menjadi korban bukan hanya pada masa damai tetapi juga dalam konflik bersenjata. Konflik bersenjata menyebabkan penderitaan yang sangat beragam bentuknya, anak - anak ada yang dibunuh, kehilangan orang tua karena terpisah satu sama lain ataupun karen amereka sudah meninggal dunia, cacat fisik, diculik, kehilangan hak atas pendidikan dan kesehatan, menderita luka, trauma batin dan emosi yang mendalam. Anak - anak dipaksa untuk meninggalkan rumahnya, mengungsi dan terusir dari tempat tinggalnya sendiri, anak - anak sangatlah rentan terhadap kekerasan, eksploitasi seksual, penyakit, kurang gizi, dan kematian. Anak dikerahkan dan digunakan untuk berperang pada garis depan berhadapan dengan musu, status gadis atau anak perempuan memberikan resiko tambahan, khusunya terhadap kekerasan seksual. 
Secara historis, munculnya anak-anak sebagai kombatan dan terlibat dalam konflik bersenjata dimulai pada sekitar abad ke-18. Anakanak secara tidak langsung telah turut serta dalam konflik bersenjata (Latvey, 2003). Pada waktu itu anak-anak hanya dapat dikatakan sebagai penggembira saja, yakni sebagai penabuh genderang perang, dari sinilah perkembangan menuju sesuatu yang tidak baik yakni dengan merekrut anak-anak untuk menjadi kadet (berfungsi membantu) pada sebuah angkatan perang. Akhirnya munculah sebuah fenomena tentara anak-anak yang tergabung dalam angkatan perang. Sejalan dengan perkembangan konflik bersenjata mulailah berkembang mengenai apa yang disebut tentara anak (child soldiers). Permasalahan (Child Soildiers) ini telah benar-benar mendunia, hal ini tidak hanya terjadi di benua Afrika yang sampai saat ini terus saja diwarnai dengan perang saudara ataupun di benua Asia, tapi juga terjadi di benua Eropa, bahkan di Benua Amerika. Pada tahun 1990an di Amerika latin terdapat tentara anak yang tergabung dalam angkatan bersenjata El-Salvador, Ekuador, Guatemala, Mexico, Nicaragua, Paraguay, Kolombia, dan Peru. Bahkan di Kolombia ada sebutan khusus untuk tentara anak yakni "Little Bells".

Sekitar 300. 000 tentara anak di bawah usia 18 tahun sekarang ini berperang dalam konflik bersenjata di sebanyak 30 Negara. Saat ini ada lebih dari 300.000 anak-anak di bawah usia 18 tahun ikut berperang di lebih dari 30 negara. Banyak dari mereka masih remaja, namun tidak sedikit juga baru berusia 10 tahun bahkan kurang dari 10 tahun. Mereka kadang bertindak lebih kejam ketika menghadapi lawan - lawannya (Latvey, 2003).

Myanmar memiliki catatan yang terburuk mengenai tentara anak. Tentara Myanmar ini sering menawan anak laki - laki di stasiun kereta api dan bus, pasar, serta tempat umum lain, mengancam mereka akan dipenjara bila mereka menolak bergabung dengan tentara pemerintah (Wagiman, 2005). Pemerintah militer di sana diperkirakan telah memiliki 70.000 tentara anak, hal ini memegang rekor jumlah tentara anak yang terbesar di dunia, tentu saja hal ini belum lagi ditambahkan dengan tentara anak yang direkrut oleh tentara oposisi di negara itu, sehingga jumlah tentara anak yang ada di negara tersebut terus mengalami peningkatan setiap tahunnya. Fenomena ini menunjukan bahwa anak-anak yang terlibat dalam konflik bersenjata bukan saja dipandang sebagai pelaku, akan tetapi sekaligus sebagai korban dari kebijakan militer atapun pemerintah negara tersebut. Dalam prespektif Hukum Humaniter jelas hal ini merupakan suatu pelanggaran hukum internasional.

Pasal 38 The Convention on the rights of the child tahun 1989 memberikan kewajiban kepada para pihak yang terlibat konflik untuk tidak merekrut anak - anak yang belum mencapaui usia 15 tahun ke dalam angkatan bersenjata dan melibatkan mereka secara langsung dalam pertempuran. Negara harus menghormati dan menjamin penghormatan atas aturan-aturan penghormatan hukum Internasional yang relevan dalam melindungi hak-hak anak.

Pasal 77 ayat 2 Optional Protocol to the Geneva Convention tahun 1949 menyatakan "The Parties to the conflict shall take all feasible measures in order that children who have not attained the age of fifteen years do not take a direct part in ostilities and in particular, they shall refrain from recruiting them in to their armed orces. In recruiting among those persons who have attained the age of eighteen years the parties to the conflict shall endeavour to give priority those who are oldest".

Ketentuan ini mengharuskan para pihak untuk memelihara dan membantu anak-anak atas dasar usia dan alasan apapun juga. Jika seorang anak yang belum mencapai usia 15 tahun terlibat dalam pertempuran dan jatuh ke tangan musuh, anak tersebut berhak atas perlindungan khusus, tanpa mempersoalkan status tawanan perang atau bukan. Lebih lanjut Pasal 4 ayat 3 Protokol Tambahan II tahun 1977 Konvensi Jenewa yang mengatur mengenai adanya konflik internal suatu negara, menyebutkan bahwa terhadap anak-anak harus diberikan perlindungan dan tindakan yang menolong mereka ketika diperlukan, anak-anak yang usianya belum mencapai 15 tahun tidak dapat direkrut ke dalam angkatan perang atau di dalam kelompok - kelompok yang terlibat atau ambil bagian dalam suatu konflik bersenjata.

International Commite of the red cros $s(I C R C)$ mengeluarkan pernyataan yang serupa, bahwa ada banyak anak -anak yang direkrut dan turut berpartisipasi di dalam suatu konflik, dan terlibat dalam kegiatan militer seperti memberikan informasi, sebagai kurir, pembawa amunisi, perlengkapan makanan atau tindakan sabotase (UNICEF, 2005). Konvensi tentang Hak anak (The Convention on the Rights of the Child) tahun 1989, yang disetujui oleh Majelis umum Perserikatan Bangsa-Bangsa pada tanggal 20 November 1989 mewajibkan negara-negara menghormati dan 
menjamin penghormatan atas aturan-aturan Hukum Internasional Humaniter yang relevan untuk melindungi anak-anak (Permanasary, dkk, 1999). Disamping itu juga Protokol tambahan Konvensi Hak Anak tersebut mengatur mengenai larangan keterlibatan anak-anak dalam konflik bersenjata (Optional Protocol to the Convention on the Rights of the Child on the Involvement of Children in armed Conflict) tanggal 25 Mei tahun 2000.

Konvensi Internasional Labour Organization Nomor 182 tahun 1999 juga memberikan pengaturan mengenai perlindungan anak dalam sengketa bersenjata khususnya mengenai perekrutan anak untuk dilibatkan dalam sengketa bersenjata. Instrumen-instrumen seperti Deklarasi Universal Hak asasi Manusia tahun 1948, dan Instrumen-Instrumen Regional seperti Deklarasi Amerika tentang hak-hak dan kewajiban manusia yang dibuat pada tahun yang sama dan mengakui secara lebih umum hak anak untuk bebas dari kekerasan, penyiksaan, dan eksploitasi. Hak-hak ini berlaku bagi setiap orang, termasuk anak - anak, dan dikembangkan lebih jauh dalam instrumeninstrumen seperti Kovenan Internasional tentang hak-hak politik dan hak - hak sipil tahun 1966 (Permanasary, dkk, 1999). Konsensus internasional yang dikembangkan mengenai perlunya suatu instrumen baru yang akan secara eksplisit meletakan dasar - dasar mengenai hak-hak anak khusus dan istimewa. Pada tahun 1989, Konvensi Perserikatan Bangsa-Bangsa tentang hak-hak anak diadopsi oleh sidang majelis umum. Konvensi ini dengan cepat menjadi perjanjian hak asasi manusia yang paling luas diratifikasi dalam sejarah perkembangan hukum internasional.

Instrumen Hukum Internasional dan nasional yang mengatur mengenai perlindungan anak memberikan pesan yang sangat jelas kepada masyarakat internasional dan pemangku kepentingan (stakeholder) di tingkat domestik bahwa suatu negara berkomitmen untuk menjamin perlindungan anak, serta menjamin penerapan undang-undang, serta kebijakan, dan program untuk mencapai sasaran itu (Permanasary, dkk, 1999). Konvensi itu mengandung standar mengenai partisipasi anak-anak dalam konflik bersenjata dan rekrutmen anak untuk terlibat dalam suatu konflik bersenjata. Negara-negara anggota tidak boleh merekrut siapapun yang berusia di bawah 15 tahun dalam bagian apapun di dalam angkatan bersenjata. Sebuah negara yang merekrut orang-orang yang berusia antara 15 sampai 18 tahun. Semua negara harus mengambil langkah-langkah yang memadai untuk mencegah pertisipasi langsung siapapun yang berusia di bawah 15 tahun dalam pertikaian, apakah di pihak pemerintah atau dipihak kelompok bersenjata lainnya (Permanasary, dkk, 1999). Berdasarkan ketentuan-ketentuan hukum internasional di atas maka dapat dikatakan bahwa penggunaan anak-anak untuk membantu kegiatan konflik bersenjata atau bahkan justru menggunakan anak-anak untuk berada di garis depan dalam suatu konflik bersenjata tidak saja merupakan pelanggaran hukum humaniter internasional tetapi juga melanggar Hak Asasi Manusia (Permanasary, dkk, 1999). Piagam PBB menyatakan bahwa salah satu tujuan didirikannya PBB adalah untuk menyebarluaskan dan mendorong penghormatan terhadap Hak Asasi Manusia dan kebebasan dasar bagi semua tanpa memandang perbedaan ras, jenis kelamin, bahasa, atau agama (Mauna, 2005).

\section{Metode}

Metode yang digunakan dalam penelitian ini adalah penelitian yuridis normatif yang merupakan salah satu studi hukum yang menggunakan literatur atau peraturan perundang-undangan yang berkaitan dengan permasalahan yang diteliti, sehingga pendekatan yang digunakan adalah pendekatan perundang-undangan, dilakukan dengan menelaah semua undang-undang dan regulasi yang bersangkut paut dengan isu hukum yang sedang ditangani (Marzuki, 2007). Penelitian ini merupakan suatu penelitian hukum yaitu suatu proses untuk menemukan aturan hukum, prinsip prinsip hukum, maupun doktrin - doktrin hukum guna menjawab isu hukum yang dihadapi.

\section{Hasil dan Pembahasan}

Hukum Humaniter pada hakikatnya menjamin perlindungan terhadap Hak Asasi Manusia. Perkembangan hukum Humaniter tidak terlepas dari perkembangan hak asasi manusia, maka negara-negara kemudian menyetujui prinsipprinsip perlindungan orang-orang yang terlibat dalam sengketa bersenjata baik secara internasional maupun secara nasional.

Sebagai suatu nilai yang diakui secara universal, pengakuan dan perlindungan terhadap Hak asasi Manusia merupakan tanggung jwab bersama yang bersifat lintas negara, artinya 
persoalan hak asasi manusia tidak hanya merupakan persoalan internal suatu negara secara tersendiri, melainkan persoalan bersama yang mendapat perhatian internasional. Anak-anak sebagai bagian dari masyarakat internasional memiliki hak untuk diakui dan dilindungi dalam hukum internasional, ketika deklarasi tentang hakhak anak internasional yang pertama diadopsi oleh Liga Bangsa-Bangsa.

Ada sepuluh asas atau prinsip dasar tentang hak anak yang diadopsi dalam deklarasi hak-hak anak tersebut (Joni \& Tanamas, 1999), yaitu:

1. Anak - anak berhak menikmati seluruh hak yang tercantum dalam deklarasi ini. Semua anak tanpa pengecualian yang bagaimanapun berhak atas hak-hak ini, tanpa membedakan suku bangsa, warna kulit, jenis kelamin, bahasa, agama, pandangan politik dan pendapat lainnya, asal-usul bangsa atau tingkatan sosial, kaya atau miskin, keturunan atau status, baik dilihat dari segi dirinya sendiri maupun dari segi keluarganya.

2. Anak-anak mempunyai hak untuk memperoleh perlindungan khusus, dan harus memperoleh perlindungan khusus, harus memperoleh kesempatan dan fasilitas yang dijamin oleh hukum dan sarana lain sehingga secara jasmani, mental akhlak, rohani dan sosial, mereka dapat berkembang dengan sehat dan wajar dalam keadaan bebas dan bermartabat;

3. Sejak dilahirkan, anak-anak harus memiliki nama dan kebangsaan;

4. Anak-anak harus mendapat jaminan. Mereka harus tumbuh dan berkembang dengan sehat. Untuk maksud itu baik sebelum maupun sesudah dilahirkan, harus ada perawatan dan perlindungan khusus bagi si anak dan ibunya. Anak-anak berhak mendapat gizi yang cukup, perumahan, rekreasi dan pelayanan kesehatan;

5. Anak-anak yang cacat tubuh dan mental atau yang berkondisi sosial lemah akibat suatu keadaan tertentu harus memperoleh pendidikan, perawatan, dan perlakuan khusus.

6. Agar supaya kepribadiannya tumbuh secara maksimal dan harmonis, anak - anak memerlukan kasih sayang dan pengertian. Sedapat mungkin mereka harus dibesarkan dibawah asuhan dan tanggung jawab orang tua mereka sendiri, dan bagaimanapun harus diusahakan agar mereka tetap berada dalam suasana yang penuh kasih sayang, sehat jasmani dan rohani. Anak-anak di bawah usia 5 tahun tidak dibenarkan terpisah dari ibunya.
Masyarakat dan penguasa yang berwenang, berkewajiban memberikan perawatan khusus kepada anak-anak yang tidak memiliki keluarga dan kepada anak-anak yang tidak mampu. Diharapkan agar pemerintah atau pihak yang lain memberikan bantuan pembiayaan bagi anak-anak yang berasal dari keluarga besar.

7. Anak-anak berhak mendapat pendidikan wajib secara Cuma-cuma sekurang-kurangnya di tingkat sekolah dasar. Mereka harus mendapat pendidikan yang dapat meningkatkan pengetahuan umumnya dan memungkinkan mereka, atas dasar kesempatan yang sama, untuk mengembangkan kemampuannya, pendapat pribadinya, dan perasaan tanggung jawab moral dan sosialnya, sehingga mereka dapat menjadi anggota masyarakat yang berguna. Anak-anak harus mempunyai kesempatan yang leluasa untuk bermain dan berekreasi yang diarahkan untuk tujuan pendidikan, masyarakat dan penguasa yang berwenang harus berusaha meningkatkan pelaksanaan hak ini.

8. Dalam keadaan apapun anak-anak harus didahulukan dalam menerima perlindungan dan pertolongan.

9. Anak-anak harus dilindungi dari segala bentuk penyia-nyiaan, kekejaman dan penindasan. Dalam bentuk apapun, mereka tidak boleh diperdagangkan. Tidak dibenarkan mempekerjakan anak-anak dibawah umur. Dengan alasan apapun mereka tidak boleh dilibatkan dalam pekerjaan yang dapat merugikan kesehatan atau pendidikan mereka, maupun yang dapat mempengaruhi perekembangan tubuh, mental atau akhlak mereka.

10. Anak-anak harus dilindungi dari perbuatan yang mengarah ke dalam diskriminasi rasial, agama maupun bentuk-bentuk diskrimansi lainnya. Mereka harus dibesarkan di dalam semangat yang penuh pengertian, toleransi dan persahabatan antar bangsa, perdamaian serta persaudaraan semesta dan dengan penuh kesadaran tenaga dan bakatnya harus diabadikan kepada sesama manusia.

Anak merupakan karunia Tuhan yang harus mendapat perlindungan, bimbingan dan pembinaan secara konsisten, karena di dalam dirinya melekat harkat dan martabat sebagai manusia seutuhnya, sehingga ia memiliki hak-hak asasi yang yang sama seperti hak- hak asasi yang dimiliki oleh individu- 
individu lainnya (Joni \& Tanamas, 1999). Secara psikologis dan biologis anak berbeda dengan orang dewasa dan rentan terhadap segala kondisi dan situasi yang dapat mempengaruhi perkembangan jiwanya. Pada umumnya anak masih labil, sehingga anak selalu digambarkan sebagai fase yang sangat penting dalam proses pertumbuhan fisik dan jiwanya. Hal tersebut dikarenakan anak termasuk dalam kelompok individu yang masih memiliki ketergantungan yang erat dengan orang lain, memiliki sifat keluguan, memiliki sifat keluguan, memiliki kebutuhan-kebutuhan khusus, serta masih membutuhkan perlindungan serta perawatan yang bersifat khusus pula.

Pasal 1 Konvensi Hak Anak menegaskan bahwa anak adalah setiap manusia yang berusia di bawah 18 tahun, kecuali bila undang-undang yang berlaku menetapkan batas awal usia dewasa yang lebih cepat.

Anak dilahirkan merdeka, tidak boleh dilenyapkan atau dihilangkan, tetapi kemerdekaan anak harus dilindungi dan diperluas dalam hal mendapatkan hak atas hidup dan hak untuk mendapatkan perlindungan dari orang tua, keluarga, masyarakat, bangsa dan negara.

Sejak abad pertengahan, hampir semua peradaban telah mengetahui peraturan guna membatasi pihak peserta tempur untuk melakukan pengrusakan terhadap musuh. Di negara-negara Iran, Yunani, Romawi, India, Cina, dan negaranegara di Afrika dan Eropa terdapat beberapa aturan guna melindungi kaum tertentu (wanita, anak-anak, orang tua, tawanan) peraturan-peraturan yang dibuat untuk melindungi wanita dan anakanak tersebut juga melarang serangan yang diarahkan pada objek tertentu seperti tempat ibadah serta mengatur tentang metode peperangan yang tidak adil seperti penggunaan racun.

Istilah Hukum Humaniter relatif baru, sehingga perlu disosialisasikan. Menurut Mochtar Kusumaatmadja, pengertian Hukum Perang dibagi atas dua bagian (Permanasari, dkk, 1999), yaitu:

\section{Ius ad Bellum}

Sama dengan "Hukum tentang perang", yaitu hukum yang mengatur dalam hal bagaimana negara dibenarkan menggunakan kekerasan senjata.

2. Ius In Bello

Sama dengan "Hukum yang berlaku dalam perang", yang dibagi dalam dua bagian:

a) Yang mengatur "cara dilakukannya perang" (Conduct of War), bagian inilah yang disebut sebagai Hukum Den Haag, yaitu keseluruhan ketentuan-ketentuan Hukum Internasional yang mengatur Metoda atau cara berperang.

b) Yang mengatur "Perlindungan orang-orang" yang menjadi korban perang (tawanan perang, angkatan perang, dan penduduk sipil). Bagian inilah yang disebut sebagai Hukum Jenewa.

Pasal 17 Konvensi IV Jenewa memepersyaratkan bahwa ketika sebuah wilayah dikepung, penguasa setempat harus mengupayakan perundingan untuk mengeluarkan anak-anak serta mereka yang terluka, sakit, berusia lanjut dan sakitsakitan. Pasal 23 Konvensi IV Jenewa mempersyaratkan bahwa semua negara harus mengijinkan masuknya perlengkapan medis yang ditujukan bagi warga sipil, dan makanan serta pakaian bagi anak-anak.

Konvensi-konvensi Jenewa tidak menyebutkan dan menjelaskan tentang kombatan atau perserta perang, tetapi langsung menyebut dan menjelaskan kriteria orang - orang yang dilindungi dan orang-orang yang ditempatkan sebagai tawanan perang. Berkaitan dengan status tawanan perang dan kombatan di atas, Protokol Tambahan I tahun 1977 memuat ketentuan tentang orang-orang yang sring dijumpai melibatkan diri atau dilibatkan dalam peperangan tetapi tidak mempunyai hak sebagai kombatan dan karenanya tidak dapat ditempatkan sebagai tawanan perang. Orang orang tersebut adalah:

1. Spies

Anak-anak sering dipakai sebagai spyatau mata-mata dalam suatu sengketa bersenjata. Dalam pasal 46 ayat (1) Protokol tambahan I tahun 1977 dinyatakan bahwa, setiap anggota angkatan perang dari suatu pihak dalam pertikaian yang jatuh ke dalam kekuasaan suatu pihak lawan ketika sedang melakukan kegiatan mata - mata tidak akan mempunyai hak atas keudukan tawanan perang.

2. Mercenaries

Dalam pasal 47 ayat (2) Protokol tambahan I Konvensi Jenewa tahun 1949 disebutkan bahwa Mercenaries atau tentara bayaran adalah setiap orang yang:

a) Direkrut khusus dari lokasi setempat atau dari luar negeri untuk bertempur dalam suatu sengketa bersenjata;

b) Melakukan, secara nyata, ambil bagian langsung dalam sengketa bersenjata;

c) Dimotifasi untuk ambil bagian dalam peperangan secara rasional oleh keinginan untuk tujuan sendiri, dan pada 
kenyataannya, dijanjikan oleh atau atas nama suatu pihak yang bersengketa, kompensasi, materi dalam jumlah yang lebih dari yang dijanjikan atau yang dibayarkan kepada kombatan - kombatan yang berpangkat dan berfungsi sama pada angkatan bersenjata pihak tersebut;

d) Bukan berkebangsaan dari suatu pihak yang bersengketa atau bukan seorang penduduk dari teritori yang diduduki oleh suatu pihak yang bersengketa;

e) Bukan anggota angkatan bersenjata dari suatu pihak yang bersengketa, dan;

f) Belum dikirim oleh suatu negara yang bukan pihak bersengketa ke pertempuran untuk tugas resmi sebagai seorang anggota angkatan bersenjata;

\section{Child Combatan}

Anak-anak dalam Protokol tambahan I Konvensi Jenewa 1949 memang tidak ditetapkan mempunyai hak untuk diperlakukan sebagai tawanan perang, tetapi disebutkan harus memperoleh keuntungan perlindungan khusus yang ditetapkan dalam Hukum Jenewa, apakan berstatus tawanan perang atau tidak. Dalam Protokol tambahan memuat ketentuan yang menyebabkan pihakpihak yang bersengketa untuk berusaha agaranak di bawah usia 15 tahun tidak ambil bagian langsung dalam sengketa bersenjata. Pasal 8 Statuta Roma menyatakan bahwa, menyerahkan anak - anak di bawah umur 15 tahun ke dalam angkatan bersenjata atau menggunakan mereka untuk ikut serta secara aktif dalam peperangan harus dianggap sebagai suatu kejahatan perang dan dihukum atas perbuatan tersebut (Soekito, 1983).

Dalam pertikaian bersenjata tidak satu pihakpun boleh menyelenggarakan pengungsian anak-anak selain daripada warga negaranya sendiri ke sebuah negara lain, kecuali untuk suatu pengungsian sementara karena alasan perawatan kesehatan atau pengobatan atau kecuali kemanan anak-anak itu di daerah yang diduduki menghendaki demikian.

Sebanyak seratus sembilan puluh dua negara telah meratifikasi Protokol serta Opsional Protokol Konvensi Hak-Hak Anak mengenai keterlibatan anak dalam konflik bersenjata. Perlindungan dan hukuman menjadi fokusnya, sementara masalah pemulihan, reintegrasi dan santunan hanya sedikit diperhatikan. Pencegahan juga dipandang oleh beberapa negara hendaknya ditangani hanya melalui legislasi aspek-aspek perlindungan dan hukuman.

Ratifikasi suatu perjanjian internasional adalah tahap yang palin penting dalam treaty making process. Ratifikasi juga berarti menyerahkan sedikit kedaulatan negara kepada suatu perjanjian internasional. Ratifikasi terhadap konvensi-konvensi internasional baik yang menyangkut perlindungan hak-hak anak maupun instrumen instrumen hukum humaniter menimbulkan kewajiban pada negara-negara pihak untuk menerapkannya ke dalam perundangundangan nasional masing-masing negara. Meskipun dalam praktek ketatanegaraan suatu negara tidak melakukan ratifikasi terhadap konvensi-konvensi internasional akan tetapi berdasarkan Konvensi Wina tahun 1969 tentang Perjanjian Internasional, ditegaskan bahwa Konvensi tersebut akan mengikat negara dan berlaku sebagai Hukum Kebiasaan Internasional (Parthiana, 2005).

\section{Pernyataan Konflik Kepentingan}

Para penulis menyatakan bahwa tidak ada potensi konflik kepentingan dalam penelitian, kepengarangan, dan/atau publikasi artikel ini

\section{Pendanaan}

Tidak ada

\section{Referensi}

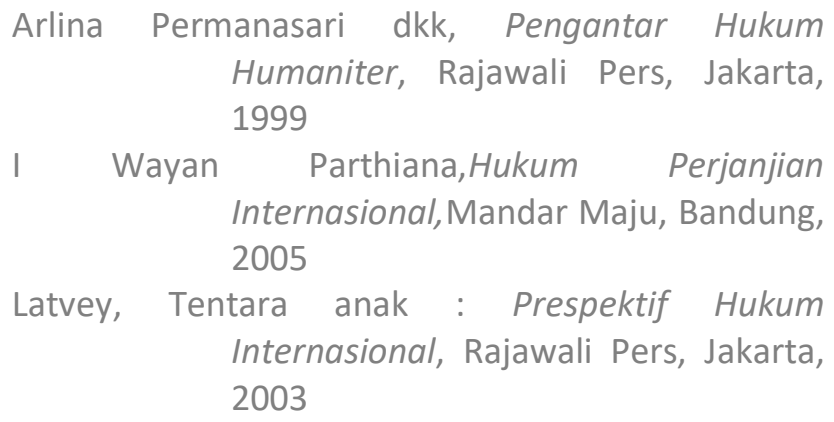

Arlina Permanasari dkk, Pengantar Hukum Humaniter, Rajawali Pers, Jakarta, 1999

I Wayan Parthiana,Hukum Perjanjian Internasional, Mandar Maju, Bandung, 2005

Latvey, Tentara anak : Prespektif Hukum Internasional, Rajawali Pers, Jakarta, 2003 
Marzuki, M.P, Penelitian Hukum, Prenada Media Group, Jakarta, 2006

Mochtar Kusumaatmadja, Pengantar Hukum Internasional, Rafika Cipta, Jakarta, 2005

Susilowati I, Konvensi Hak Anak Sahabat Remaja Pkbi Jogjakarta, Ghalia Indonesia, Jakarta, 2003

Unicef dan Interperliementary Union Internasional Review Of The Red Cross, PT. Alumni, Bandung, 2005

Submitted December 9, 2019

Revision received January 12, 2019

Accepted January 25, 2019

Published online February 3, 2020
Wahyu Wagiman, Hukum Humaniter Hak Asasi Manusia, Seri Bahan Bacaan Khusus HAM Untuk Pengacara $X$, Akademik Presindo, Jakarta, 2005

Konvensi Hak Anak (The Convention on the Rights of the Child) Tahun 1989

Protokol Tambahan Konvensi Jenewa Tahun 1949

\section{How to cite?}

Hetharie, Y., \& Hetharie, Y. (2020). Humanitarian Law Perspective on the Protection of the Rights of Children in Armed Conflicts. Law Research Review Quarterly, 6(1), 69-76. https://doi.org/10.15294//rrq.v6i1.36657 
